\title{
東京の生物多様性とその展望
}

\author{
沼田真 也*

\section{Current Status and Perspectives of Biodiversity in Tokyo}

\author{
Shinya NUMATA*
}

[Received 22 February, 2012; Accepted 9 October, 2012]

\begin{abstract}
Tokyo, the capital of Japan is one of the largest cities of the world. The administrative area of the Tokyo Metropolitan government covers the 23 special wards of Tokyo to the east, 26 cities to the west (Tama) and two outlying island chains (Izu and Bonin). Despite Tokyo being relatively small in area, it has a rich biodiversity that requires conservation efforts. I review the current status of the natural environment and biota (especially, flora of vascular plants and mammalian fauna) and discuss perspectives of biodiversity in Tokyo. There are different types of ecosystems in Tokyo: urban, secondary forest and agriculture (Satoyama), and oceanic island ecosystems. Different types of landscape support different habitat specialists. In Tokyo, the total numbers of wild plant and mammal species were estimated to be 4323 and 51, respectively. On the Izu and Bonin islands, species richness is relatively low, but endemism is high. The four principal pressures directly driving biodiversity loss (habitat change, abandonment of agricultural landscape management, pollution and invasive alien species, and climate change) are either constant or increasing in intensity in Tokyo. Although nature conservation has had significant results in maintaining biodiversity in urban and agricultural landscapes, there may be an emerging problem of human wildlife conflict in urban area due to biodiversity conservation projects in Tokyo. On the oceanic islands of Tokyo, alien species still seriously threaten endemic species of some taxa despite eradiation efforts. In 2010, Japan hosted COP-10 to the Convention of Biological Diversity (CBD). The results of COP-10 have had great impacts on policy and practices for conserving and managing biodiversity in Japan. Considering nature to be mostly anthropogenically-influenced in Tokyo, promoting a public understanding of biodiversity is the key to drawing up an urban planning framework for the sustainable management of biodiversity.
\end{abstract}

Key words : biodiversity, Bonin islands, Izu islands, Satoyama, secondary nature, Tama, The 23 special wards of Tokyo, urban ecosystem

キーワード : 生物多様性, 小笠原諸島, 伊豆諸島, 里山, 二次的自然, 多摩, 東京 23 区, 都市生態系

\footnotetext{
* 首都大学東京都市環境科学研究科観光科学域

* Department of Tourism Science, Graduate School of Urban Environmental Sciences, Tokyo Metropolitan University, Hachioji, 192-0397, Japan
} 


\section{I.はじめに}

\section{1）生物多様性とは何か}

「生物多様性 (Biodiversity)」は「生物学的多 様性 (Biological Diversity)」からつくられた造 語であり（Wilson and Peter, 1988)，現在の自然 環境問題の重要キーワードとして世界中に普及し ている（鷲谷・矢原, 1996）。2010 年には名古屋 で生物多様性条約第 10 回締結国会議 (COP-10) が開催されたのを機に，多くのメディアを通じて 生物多様性という言葉が頻繁に登場するように なった。しかし，生物多様性はさまざまな意味で 用いられており, その内容を適切に理解すること は意外と難しい。生物多様性条約 (Convention of Biological Diversity）によれば，生物多様性の定 義は「すべての生物（陸上生態系，海洋その他の 水界生態系，これらが複合した生態系その他生息 または生育の場のいかんを問わない）の間の変異 性をいうものとし，種内の多様性，種間の多様性 および生態系の多様性を含む」とされている。こ の生物多様性は 3 つの階層に分けられており, 種 の多様性とはさまざまな種の生物が存在している こと, 遺伝的多様性は同じ種であっても個体差が あること，生態系の多様性とはさまざまな環境に おけるさまざまな生態系が存在することを意味し ている。このように生物多様性とは遺伝的, 生態 学的に変異をもつような生物群がさまざまな生態 系において存在する状態をさすものである。今日 地球上でみられるさまざまな生物は約 40 億年を かけて育まれた生物進化 (と絶滅) の結果であり, 生物が有する多用な歴史を包含するような概念と もいえる。「生物多様性」は私たち人間社会が生 態系を通じて受けているさまざまな恩恵（生態系 サービス）の基盤要素であるため，学術的な重要 性に留まらず，私たちの社会においてもきわめて 重要な役割を担うものである（Millennium Ecosystem Assessment, 2005)。

\section{2）生物多様性の現状}

生物多様性が損失するというのはどういうこと か? 生物種, 個体群の絶滅というプロセスを経 て，生物多様性の損失が進んでいく。一般に，生
態系の多様性が失われれば，さまざまな環境に適 応している生物種は絶滅に向かう。そして遺伝的 多様性が失われれば，環境変動や個体群の人口学 的変動による影響を受けやすくなり，生物集団が 徐々に縮小していく絶滅の渦に巻き込まれる（例 えば, プリマック・小堀, 2008)。世界的にみれば生 物多様性を構成する遺伝子，種，生態系における すべての階層で損失が継続している。2010 年に出 版された生物多様性概況 3 (Global Biodiversity Outlook 3) では，世界的に保護地域の面積は増加 し，特定種の保全は進展しつつあること，一方で 両生類，サンゴ，植物種の絶滅危惧種をめぐる状 況は悪化し, 野生の脊椎動物が減少していること, さらに世界の大部分で生息地の減少と分断化が進 行していることが強調されている (Secretariat of the Convention on Biological Diversity, 2010)。

日本の生物多様性の状況も評価され，1950 年 代後半から 2010 年までの変化とその要因がとり まとめられている（環境省生物多様性総合評価検 討委員会, 2010)。世界の傾向と同様に，日本で もすべての生態系で人間活動にともなう生物多様 性の損失があり，その損失は今も続いている。と くに，陸水生態系，沿岸・海洋生態系，島嶼生態 系における生物多様性の損失が大きい。これらの 生物多様性の損失要因については 4 つの危機と してまとめられている（表 1)。

第 1 の危機は開発・改変, 直接的利用, 水質 污濁などによる人為による直接的な生息地の破 壊, 分断, 劣化であり, とりわけ開発・改変の影 響力が大きい。とくに，高度経済成長期には，急 速で規模の大きな開発・改変によって, 都市は拡 大し，河川などの陸水域や沿岸域は開発が進み, 自然性の高い森林, 農地, 湿原, 干潟といった生 態系の規模が著しく縮小した。すでに，人為的に 改変されていない植生は国土の約 $20 \%$ に満たな いため，新たな開発による生態系の破壊は少な く，第 1 の危機によって生物種が絶滅する速度 はやや緩和されているといえる。

第 2 の危機は里地里山等の利用・管理の縮小 である。里地里山は集落とそれをとり巻く雑木林 などの二次林，農地，ため池，草原などで構成さ 
表 1 生物多様性国家戦略 2010 に打ける生物多様性の危機.

Table 1 Four biodiversity crises identified by the national biodiversity strategy in Japan.

\begin{tabular}{|c|c|}
\hline 危機の種類 & 内容 \\
\hline $\begin{array}{l}\text { 第 } 1 \text { の危機 } \\
\text { (人間活動や開発による危機) }\end{array}$ & $\begin{array}{l}\text { 人間活動や開発等, 人が引き起こす負の影響要因による生物多様 } \\
\text { 性への影響を指す. 例えば, 種の減少や絶滅, 開発行為等による } \\
\text { 生態系の破壊, 分断, 劣化を通じた生物の生育・生息空間の消失 } \\
\text { 等があげられる. }\end{array}$ \\
\hline $\begin{array}{l}\text { 第 } 2 \text { の危機 } \\
\text { (人間活動の縮小による危機) }\end{array}$ & $\begin{array}{l}\text { 自然に対する人間の働きかけが縮小撤退することによる影響を指す. } \\
\text { 例えば, 生活様式・産業構造の変化, 人口減少など社会経済変化 } \\
\text { に伴い, 自然に対する自然の働きかけが弱まることによる里地里 } \\
\text { 山などの環境の質の変化, 種の減少などがあげられる. }\end{array}$ \\
\hline $\begin{array}{l}\text { 第 } 3 \text { の危機 } \\
\text { (人間によりもち込まれた } \\
\text { ものによる危機) }\end{array}$ &  \\
\hline 地球温暖化の危機 & $\begin{array}{l}\text { 地球温暖化によりもたらされる種の減少, 絶滅, あるいは生態系 } \\
\text { の変化を通じた生息地・生育地の縮小, 消失を指す. 全球平均気 } \\
\text { 温の上昇が } 1.5 \sim 2.5 \text { 度を超えた場合, これまで評価対象となっ } \\
\text { た動植物種の役 } 20 \sim 30 \% \text { 絶滅リスクが高まる可能性が高いと } \\
\text { 予測されている. }\end{array}$ \\
\hline
\end{tabular}

れる景観で，薪や炭，堆肥などの生産など，伝統 的な農業のための利用を通じて環境が形成・維持 されてきた（武内ほか, 2001）。この里地里山は, 二次的自然環境に適応してきた生物の生息・生育 環境として，また，食料，肥料，木材，燃料など 自然資源の供給源としての役割を果たし，現在で も良好な景観の提供や文化の伝承の観点からも重 要な地域である。しかし，エネルギー革命以降 は，自然資源に対する需要の低下に伴い里地里山 の二次的自然に対する依存度が低下し, 結果とし て人為による働きかけが減少したため, 植生遷移 や景観の荒廃が進行している。とくに, 里地里山 が残存する地域では過踈化や高齢化などによる社 会問題も顕著であるため, この危機は今後も増大 していく可能性が高い。

第 3 の危機は人為的に外来種, 化学物質など が生態系にもち込まれることによる生態系の攪乱 である。外来種は食用, 愛玩用, 観賞用のために 意図的にもち込まれるだけでなく, 輸入貨物に混 入・付着など非意図的なもち込みによっても侵 入し，とくに陸水生態系や島嶼生態系に扔いて
深刻な脅威をもたらす（村中・石濱, 2010）。例 えば，通称ブラックバスと呼ばれるオオクチバス (Micropterus salmoides) は，1970 年代には意図 的な放流によって急速に分布を拡大させ，1990 年代には北海道を除く都府県で生息が碓認される ようになった。他方，化学物質による生物への影 響に関しては 1970 年代から改善の傾向を示して いると考えられるが, 農薬や化学肥料の不適切な 使用は農地やその周辺に生息する生物に対して影 響を与元続けている。とくに，污染物質（農薬な ど）の生物濃縮によって食物連鎖の頂点に位置す る猛禽類などの動物が影響を受け，さらには間接 的に他の生物に対しても影響が及ぶことが問題で ある（藤森ほか, 1999）。

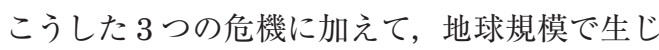
る気候変動による影響を大きな課題としてあげる 必要がある。地球温暖化は，種の分布やフェノロ ジー (生物季節) の変化を通じて, 生態系の規模 の縮小，質の低下，種の個体数の減少や分布の縮 小を引き起こす要因となる。とくに高山植生や州 ンゴ礁など一部の脆弱な生態系で懸念されている。 


\section{3）生物多様性に関する国内外の取り組み}

世界的に生物多様性の危機が増加しつつある現 状に対応するため, CBD（生物多様性条約）に 基づく取り組みがなされている。この条約は, 1992 年にリオ・デ・ジャネイロ (ブラジル) で開 催された国連環境開発会議（地球サミット）で採 択された国際条約のひとつで, 1993 年に発効さ れた。2012 年現在, 193 の国と地域が締約し, （1）生物多様性の保全，（2）生物多様性の構成要 素の持続可能な利用，（3）遺伝資源の利用から生 ずる利益の公正かつ衡平な配分が目的として掲げ られている（渡邊ほか, 2011）。この条約の第 6 条「保全及び持続可能な利用のための一般的な措 置」においては，締約国が生物多様性国家戦略を 策定することを義務づけている（環境省, 2010）。 日本の生物多様性国家戦略 2010 では, 生物多様 性の保全や利用に向けて中長期目標が設定され, 国内外の取り組み強化や国内外での取り組みの充 実，強化が掲げられている。この条約を受け， 2008 年 6 月には生物多様性基本法 (平成 20 年法 律第 58 号）が公布・施行され，生物多様性の保 全と持続可能な利用について基本原則が定めら れ，国，地方公共団体，事業者，国民および民間 の団体の責務が規定されている。

CBD における第 10 回締約国会議（COP-10） が 2010 年 10 月 11 日から 29 日まで愛知県名古 屋市で開催された。この COP-10では生物多様性 を守る国際目標, 遺伝資源へのアクセスと利益配 分 (ABS: Access and Benefit Sharing) ルールが 議論され，ABS に関する名古屋議定書や 2011 年 から 2020 年までの新戦略計画・愛知目標が採択 された。経済学的な観点から生物多様性の言失に ついて世界レベルで研究された成果をとりまとめ た，“生物多様性版スターン・レビュー”と称され る「生物多様性の経済学 (TEEB: The Economics of Ecosystems and Biodiversity)」報告書が公表 され，生物多様性の損失や劣化の現状に関して科 学的知見を集め, 各国政府の政策や行動を促す基 盤として「生物多様性と生態系サービスに関する 政府間科学政策プラットフォーム（IPBES: Intergovernmental Science and Policy Platform on
Biodiversity and Ecosystem Services)」について の議論がなされた（中静, 2011）。このような COP10 の成果を踏まえ，国内においても社会経済活 動のなかに生物多様性に関する課題を組み込み, さまざまな主体が行動するための施策が行われて いる（環境省, 2010）。

\section{II. 東京都の生物多様性とその危機}

\section{1) 東京の自然環境の概要}

本稿で注目する東京都は日本の司法・立法・行 政・経済の中心地でもあるだけでなく, $2,188.67$ $\mathrm{km}^{2}$ の土地に 1300 万人の人口を抱える巨大都市 である。東京都には本土部 (区部, 多摩地域), 伊豆諸島，小笠原諸島が含まれる（図 1)。その ため, 東京といっても小笠原諸島の亜熱帯植生, 伊豆諸島の暖温帯植生や火山植生，区部の暖温帯 植生や多摩西部 (奥多摩) の冷温帯植生, 要高山 帯植生までさまざまである。

東京都は世界でも有数な大都市であるにもかか わらず，多彩な自然環境を有する 3 つ国立公 園を有する。秩父多摩甲斐国立公園は東京・埼 玉・山梨・長野の 1 都 3 県にまたがる国立公園 で秋川渓谷と奥多摩湖周辺が含まれる。富士箱根 伊豆国立公園は東京・山梨・神奈川・静岡の 1 都 3 県にまたがる国立公園で，東京都には伊豆諸島 の大島, 利島, 新島, 式根島, 神津島, 三宅島, 御蔵島，八丈島の 8 島が含まれている。小笠原 諸島のほとんどが小笠原国立公園に指定されてい る。八王子市郊外の山麓から高尾山周辺は明治の 森高尾国定公園に指定されている。東京都が指定 する保全地域として 1 . 自然環境保全地域，2. 森 林環境保全地域, 3. 里山保全地域, 4. 歴史環境 保全地域, 5. 緑地保全地域がある。現在, 3 区 23 市 1 村に 48 地域 $\left(7,507,736 \mathrm{~m}^{2}\right)$ が指定され ている（東京都環境局, 2012)。本土部には $6 つ$ の都立自然公園（都立滝山自然公園，都立高尾陣 場自然公園, 都立多摩丘陵自然公園, 都立狭山自 然公園, 都立羽村草花丘陵自然公園, 都立秋川丘 陵自然公園）がある。このような自然環境は東京 都の自然環境を代表するものであり，野生生物 (とくに陸棲）のための生育地を提供している。 

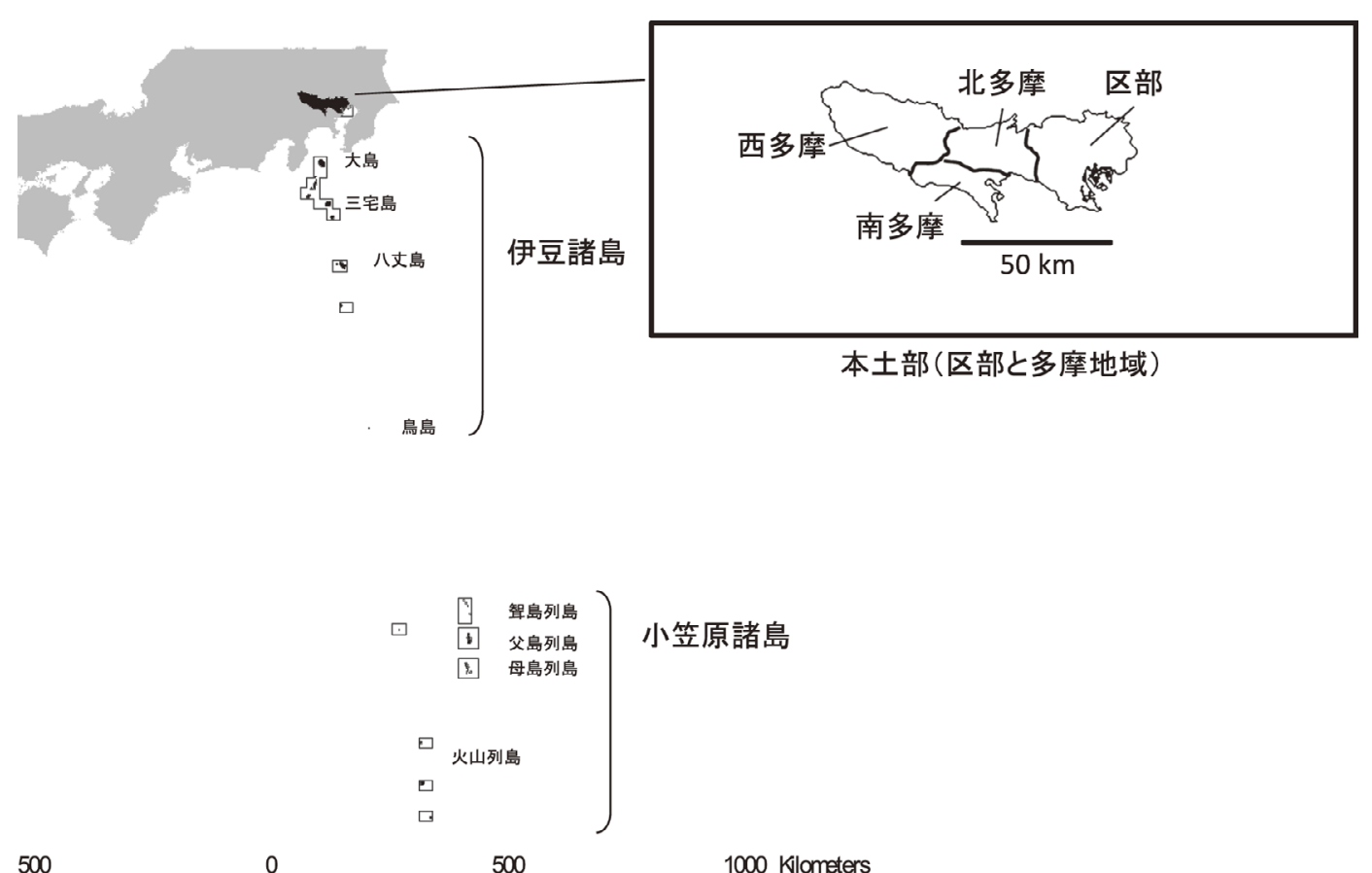

図 1 東京都本土部と島.

Fig. 1 Location of Tokyo metropolis, Izu islands and Bonin islands.

東京にはどのくらいの野生生物が存在するので あろうか？ 1998 年に公開された東京都野生生物 種目録（東京都環境保全局, 1998）には東京都に生 育する野生生物種として，植物が 4323 種，哺乳 類は 51 種，鳥類 422 種，は虫類 30 種，両生類 18 種淡水魚類 90 種, 昆虫類 2648 種が記録され ている。植物に注目すると，本土部（区部，多摩 地域）においては 3421 種，伊豆諸島においては 1313 種，小笠原には 654 種が記録されている（図 $2 \mathrm{a}$ )。哺乳類の場合には，本土部 (区部，多摩地域) においては 43 種，伊豆諸島においては 17 種，小 笠原には 1 種（オガサワラオオコウモリ: Pteropus pselaphon）が生息している。ただし，小笠原諸 島において外来種として定着しているクマネズミ (Rattus rattus)，ノヤギ (Capra hircus)，ノネ コ（Felis catus）が含まれていないなど，不完全 な部分もあるため, 今後の更新作業が重要であ る。伊豆諸島と小笠原諸島の植物に関しては，首
都大学東京牧野標本館が所蔵する「海洋島植物標 本データベース」があり，16,000 点以上の被子 植物標本の標本画像などを参照することができる （首都大学東京牧野標本館, 2010)。

しかし，残念なことにこれらの目録に掲載され ている種のいくつかはすでに絶滅した，もしくは 絶滅が危惧される状態にある。絶滅危惧種とは, 個体数の少ない，もしくは急速に減少したため絶 滅の恐れがある種のことであり，個体群サイズや その減少率から算出された絶滅の危険性によって 絶滅危惧 I 類，絶滅危惧 II 類に分類されている (矢原・川窪, 2002)。絶滅危惧 I 類は, ごく近い 将来絶滅の危険性の高い種である「絶滅危惧 IA 類 $(\mathrm{CR}) 」$ と, IA 類ほどでないが，近い将来に 絶滅の危険性の高い種である「絶滅危惧 IB 類 $(\mathrm{EN}) 」 に$ 分けられる。「絶滅危惧種 II 類 $(\mathrm{VU}) 」$ は，絶滅の危機が増大している種と定義される。 絶滅の危険度は小さいが, 生息条件の変化によっ 
（a）東京都野生生物種目録掲載種数

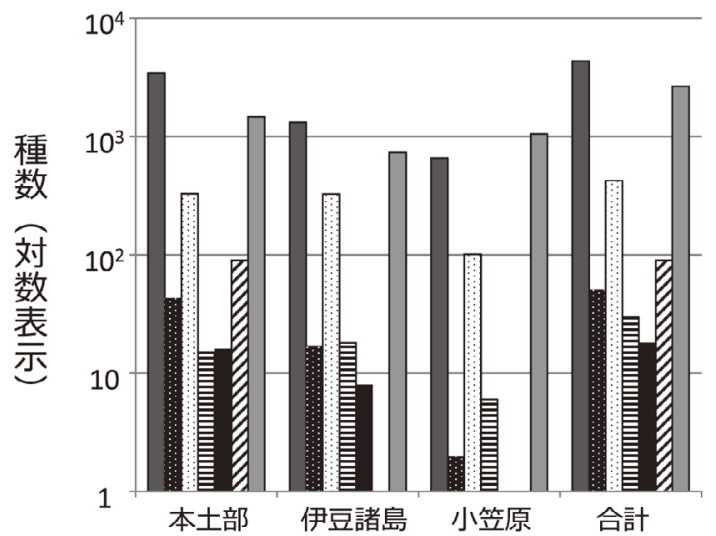

（b）東京都の保護上重要な野生生物種数

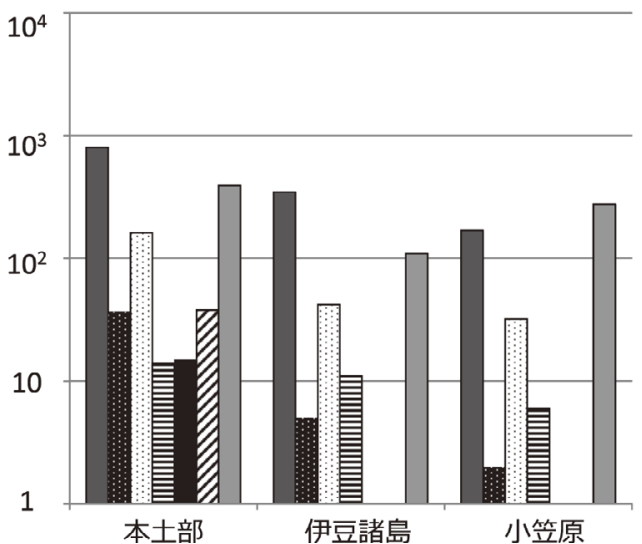

図 2 東京都の野生生物.（a）野生生物種目録掲載種数, (b) 保護上重要な野生生物種数. 東京都環境保全局（1998）, 東京都環境局 $(2010,2011)$ のデー夕をもとに作 + 成. 横軸は対数表示.

Fig. 2 Wildlife species in Tokyo Metropolis. (a) Comparison of numbers of wildlife species listed among regions (mainland, Izu islands, and Bonin islands). (b) Comparison of numbers of endangered wildlife species among regions (mainland, Izu islands, and Bonin islands). Data Source: Bureau of Environment, Tokyo Metropolitan Government (1998, 2010, 2011).

て絶滅危惧に移行する可能性のある種を「準絶滅 危惧種（NT)」としている。これらの種をまとめ たレッドリストや生態的な情報などを盛り込んだ レッドデータブックはさまざまな組織，例えば国 際機関である IUCN (国際自然保護連合)，国(環 境省), 自治体 (都道府県) が作成しており, そ れぞれのリストでは絶滅の意味合いが異なる。

2010 年に出版された東京都レッドデータリス 卜 (東京都の保護上重要な野生生物種)によると, 本土部（区内，北多摩，南多摩，西多摩）では 800 種の植物が東京都の絶滅または絶滅が危惧 される種として選定されている（東京都環境局, 2010) (図 2b)。これら 800 種のうち 182 種（約 $22.8 \%$ ）が環境省のレッドリストに登録されてい る。また， 84 種はすでに東京都の本土部におい て分布が確認できない状態にある。伊豆諸島では 348 種，小笠原諸島では 169 種の植物が絶滅ま たは絶滅が危惧される種として選定され，うち伊 豆諸島では 99 種小笠原諸島では 35 種が環境省 のレッドリストにも登録されている（東京都環境
局, 2011)。哺乳類については，本土部では 37 種，伊豆諸島では 5 種，小笠原諸島では 2 種が 選定されているが，本土部ではオオカミ（Canis lupus) とカワウソ (Lutra lutra nippon) の 2 種 が，小笠原諸島ではオガサワラアブラコウモリ (Pipistrellus sturdeei) がすでに絶滅した。

以後，本土部，伊豆諸島，小笠原諸島の自然環 境と植物と哺乳類からみた生物相について述べ る。

\section{2）本土部の自然環境と生物多様性}

本土部の主要部分は関東平野に位置し，東京湾 に面した地域であるが，区部と西部の多摩地域で は主要な生態系や景観は大きく異なる。そこで, 東京都の保護上重要な野生生物種（東京都環境局, 2010）に従い，本土部を区部と多摩地域に分け， 多摩地域はさらに北多摩，南多摩，西多摩地域に 分けてその自然環境と生物相を概観する。北多摩 は国分寺，立川，府中など，南多摩は八王子，多 摩，町田など，西多摩は奥多摩町，青梅市，あき る野市などが含まれる（図 1）。東側の区部はき 


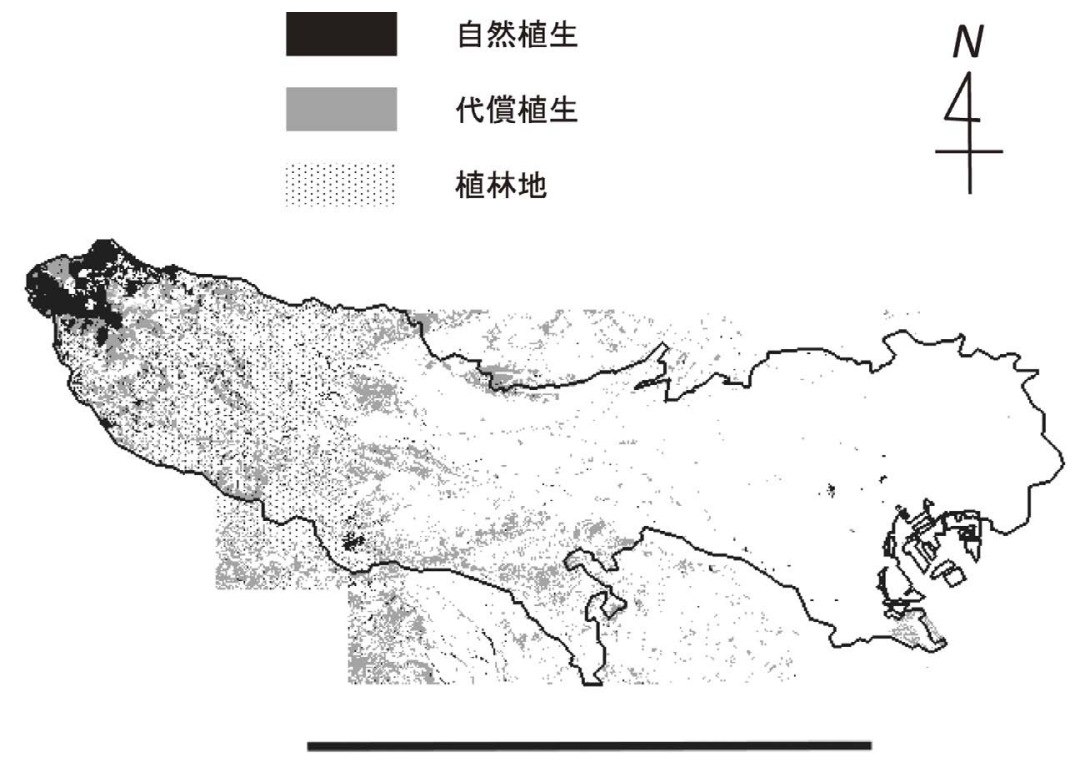

$60 \mathrm{~km}$

図 3 東京のおもな植生. 自然植生（コケモモ-トウヒクラス域自然植生，ブナクラス域自然植生，ヤブッバキ クラス域自然植生)，代償植生（コケモモ-トウヒクラス域代償植生，ブナクラス域代償植生，ヤブッバキ クラス域代償植生）と植林地, 耕作地植生（アカマッ植林）。第 6 回・第 7 回自然環境保全基礎調査植生調 査環境省自然環境局生物多様性センターのデータから作成.

Fig. 3 Vegetation map of mainland Tokyo Metropolis. Natural and secondary vegetation (subalpine conifer forest, broad-leaved deciduous forest, and broad-leaved evergreen forest zones) and plantation were mapped. Data were taken from the results of the 6th and 7th Vegetation Survey conducted by the Ministry of Environment of Japan.

わめて都市化が進んでおり，西へ行くほど森林が 増えるが，人為が加えられていない自然植生は少 なく，ほとんどは人為的な影響が加えられた後に 成立した代償植生か植林地である（図 3)。とく に陸棲の野生生物の生息には森林，農地，原野の 存在や面積が大きく影響すると考えられるが（例 えば, 尾崎ほか, 2008)，2006 年における区部の 森林面積（樹林，竹林など）は 42.4 ha $(0.1 \%)$ しかなく, 農用地面積（田，畑，樹園，採草放牧 地など）も 705.6 ha (1.1\%) や原野（野草地など） 530.5 ha $(0.8 \%)$ ほどしかない（東京都都市整備 局, 2008)。一方で，多摩地域には比較的多くの 森林や農地が残されており，2007 年における森 林面積は 56,458.0 ha (48.7\%), 農用地面積は $6,352.5$ ha $(5.5 \%)$ や原野は 2,589.9 ha (2.2\%) であった（東京都都市整備局, 2009）。

\section{2-1）区部}

区部ではいわゆる都市生態系が卓越する。この 地域では潜在的には暖温帯のカシ・シイ類, ヤブ ツバキ (Camellia japonica)，ムクロジ(Sapindus mukurossi）などの樹種から構成される照葉樹林 が優占するような森林となるが，ほとんどの自然 植生，代替植生は残されておらず，市街地や工場 地帯などの無植生地が大部分を占めている（宮脇, 1986)。このような都市生態系においては生息地 の破壞，化学物質等による環境污染，外来種の導 入，野生生物資源の過㮃利用などの影響を受ける ため生物相は一般にきわめて貧弱で，特殊な生態 系といえる (Puppim de Oliveira et al., 2011)。 森林生態系を有するような自然環境は皇居，新宿 御苑，明治神宮内外苑一带など都心部の西側にわ ずかに残されているのみである。都心の中心に位 置する皇居，とくに吹上御苑を中心とした地域は 
昭和 12 年から庭園やゴルフ場としての手入れが 行われなくなり, それ以降野生種が著しく繁殖 し，武蔵野の自然の様相を呈するようになった 二次的自然である（小山ほか, 2000; 近田ほか, 2000)。大都市の中心で周囲は高層ビルに囲まれ ているにも関わらず，1366 種の植物（小山ほか, 2000)，ハクビシン (Paguma larvata) やタヌキ (Nyctereutes procyonoides) などの中型哺乳類 (遠藤ほか, 2000)，69種の鳥類（武田ほか, 2000） などが観察される。

\section{2-2）多摩地域}

多摩地域はかつてその大部分が水田, 畑地, 森 林であったが，第二次世界大戦後の都市化の波に よって急激に自然環境が失われていった（沼田・ 小原, 1982)。北多摩地域では多くの地域が都市 化によって植生を失い，森林を有するような自然 環境はスポット的に残されているにすぎない。南 多摩の丘陵地にはコナラ (Quercus serrata) やク ヌギ（Quercus acutissima）が優占する二次林な どの代償植生が部分的に残されていたが（例えば, 宮脇, 1986)，1965 年からはじまった多摩ニュー タウン開発によって, 大規模な宅地造成が行わ れ，この地域に多くみられた里山景観は大きく変 容した。Ichikawa et al. (2006) は明治時代に作 成された迅速測図原図, 空中写真, 衛星画像を利 用して分析を行い, 多摩丘陵鶴見川流域（町田市 鶴川近辺）において 1880 年から 2001 年までの 間に樹林地の面積は $37 \%$ に, 畑地は $26 \%$ に減少 し, 市街地の面積はおよそ 25 倍に増加したこと を示した。高度経済成長期において，急激な自 然環境の喪失を経験したのが北多摩, 南多摩地 域の特徴である。一方, 西多摩には山地西北部 ではブナ (Fagus crenata) など落葉広葉樹林の 自然植生がみられるが，この地域を除き，スギ (Cryptomeria japonica), ヒノキ (Chamaecyparis obtusa）の植林地が優占している（図 3）。

\section{2-3）本土部の植物}

本土部の植物については, 800 種が絶滅または 絶滅の恐れがある種として選定され，1998 年と 比べて 158 種増加したが，都における絶滅は 68 種となった（東京都環境局, 2010)。また， 800 種
のうち，環境省のレッドリストでは 9 種が絶滅 危惧 IA 類 $(\mathrm{CR})$ に, 24 種が絶滅危惧 IB 類 $(\mathrm{EN})$ に, 92 種が絶滅危惧 II 類 (VU) に, 60 種が準絶 滅危惧 (NT) とされている。ただし, 地域によっ て大きく様相が異なり（図 4), 区部ではもともと 分布していない種を除いた 380 種のうち, 166 種 がすでに絶滅し，70 種が情報不足もしくはデー 夕がないとされている。絶滅種数については北多 摩では 89 種, 南多摩では 47 種, 西多摩では 24 種と西側になるにつれて減少するが，北多摩，南 多摩，西多摩においてもともと分布していない種 を除いた種数は，それぞれ 406 種，536 種，669 種と西側になるにつれて増加する（図 4a）。この ように，絶滅が危惧される植物種数は自然が残さ れた西部地域ほど多く, 生物多様性の保全のため の取り組みが必要とされている。

\section{2-4）本土部の動物}

本土部の動物については, 植物とは若干様相が 異なる。かつては東京都心にも多くの野生の哺乳 類が生息していたものの，区部においては現在多 くの野生生物は姿を消し, カワネズミ（Chimarrogale platycephala), キツネ(Vulpes vulpes) など含めた 20 種が絶滅したと考えられている。 絶滅の恐れがある種については，ヒナコウモリ (Vespertilio sinensis) が絶滅危惧 II 類 (VU) に分 類されている。アズマモグラ (Mogera imaizumii) とアカネズミ(Apodemus speciosus) は区部に生 息する数少ない哺乳類種であり，現時点において 絶滅の可能性は低いと考えられるが，比較的良好 な環境が保たれていることを指標とする種として 注目され，留意種に分類されている。

区部で卓越する都市生態系においては 1 . 野生 哺乳類，2. 飼育哺乳類もしくは逃げ出したもの, 3. 都市生態系内に生態的地位をもち, 飼育され ていないノイヌ (Canis familiaris)，ノネコなど の 3 タイプの哺乳類に分類される（沼田, 1987）。 しかし, 近年は, 都心においてもタヌキやハクビ シンのようにこれらのタイプにあてはまらない野 生生物の生息が頻繁に報告されるようになった。 区部においては杉並区，世田谷区を筆頭に，練馬 区，板橋区，新宿区などの区部西側での目撃件数 




図 4 東京都本土部の保護上重要な（a）植物種と（b) 哺乳類種における地域区分とカテゴリー. CR：絶滅危惧 IA 類, EN : 絶滅危惧 IB 類, VU：絶滅危惧種 II 類, NT：準絶滅危惧種, DD：デー夕不足。絶滅種（EX), 野外絶 滅種（ER）は除いてある。東京都環境局（2010）に掲載されているデー夕をもとに作成.

Fig. 4 Comparisons of numbers of threatened (a) plant and (b) mammal species among regions (ward area, northern Tama, southern Tama, and western Tama). Of the categories, extinct (EX) and extinct in the wild (EW) are not shown on each graph. CR: critically endangered, EN: endangered, VU: vulnerable: NT; near threatened, and DD: data deficient. Data Source: Bureau of Environment, Tokyo Metropolitan Government (2010).

が多いが，江戸川区や荒川区などの区部東部にお いてもタヌキが目撃されている（宮本, 2012）。

北多摩地域は情報がそしいが, キツネ，ニホン リス (Sciurus lis)，カヤネズミ(Micromys minutus）が生息しているようである。南多摩地域は北 多摩地域より情報は蓄積されているが，コウモリ類 を中心に情報がない種も多い。八王子西部にはツ キノワグマ (Ursus thibetanus) が生息しており, 絶滅危惧 IA 類 (CR) に分類されている。南多摩 地域では準絶滅危惧 (NT), 情報不足 (DD) まで 含めると現在生息する 27 種中 10 種 $(37.0 \%)$ が 何らかのランクに分類されている。西多摩地域 は，一部が秩父多摩甲斐国立公園に指定され，自 然環境が比較的良好の保存されている。この地域 では関東山地にみられるほぼすべての哺乳類が確 認され, オコジョ (Mustela erminea) やカモシ カ (Capricornis crispus) など高山性の哺乳類も 生息しており，東京都の生物多様性保全上重要な 地域となっている。

\section{3) 伊豆諸島，小笠原諸島の自然環境}

伊豆諸島と小笠原諸島はフィリピン海プレート の東縁に位置し, 約 4,800 万年前に伊豆・小笠原 弧と呼ばれる海洋性島弧として誕生した。最北の 大島（北緯 34 度 45 分，東経 139 度 22 分）から ほほ南に, 利島, 鵜渡根島, 新島, 式根島, 神津 島，祇苗島，恩馳島，三宅島，大野原島，御蔵 島，蘭灘波島，八丈島，八丈小島，青ヶ島，須美 寿島，鳥島の各島からなる。これらの島々は青ヶ 島を除き富士箱根伊豆国立公園に指定され，各島 のほぼ全域が，自然公園法によって特別地域に指 定され，開発等において種々の規制がある。

\section{3-1）伊豆諸島}

伊豆諸島の島々は火山もしくはカルデラ式海底 火山の外輪山が海面より高くなったものである。 北部の大島や神津島などについて議論があるもの の，八丈島や青ヶ島は一度も本土と陸続きになっ たことがない海洋島である。後述する小笠原諸島 も一度も本土と陸続きになったことがない海洋島 であるが，本土からの距離が大きく異なることを 
反映し，生物相は明らかに異なる。伊豆諸島は植 物区系として伊豆半島や箱根火山と同じ区域に含 まれるが，海流の影響を受けているため，距離的 に近い伊豆半島や房総半島の低地植生とも異なっ ている（宮脇, 1986）。植生や植物種数は基盤の 相違，地史的な古さの違いや面積により島ごとに 異なる（表 2)。本州から近距離に位置する大島 は頻繁に噴火を繰り返す三原山があり，さまざま な遷移段階にある植物群落をみることができ，八 丈島では火山活動の歴史が異なる東山（三原山） と八丈富士で優占する樹種が異なる（上條・奥富， 1993)。

伊豆諸島の植生の基盤としての植物相の特性は ほとんどの島にカシ類が自生していないことであ る（宮脇, 1986)。伊豆諸島内でも島によって特徴 は異なるが，一般に温暖多湿であるため，スタジ イ (Castanopsis sieboldii) やタブノキ (Machilus thunbergii）などが優占する常緑広葉樹林の極相 林がみられる（上條・奥富，1993）。ただし，日 本列島の照葉樹林は過去に大陸と陸続きであっ たため非常に似通っているのに比べて，伊豆諸 島および小笠原列島の照葉樹林は独自性が高い (宮脇, 1986)。

一方で，先史時代から人々が暮らしており，多 くの植生で人為影響がみられるのも特徵である （大山，1999）。また，火山に起源を有するため, 噴火による裸地形成から極相にいたる植生の遷移 の諸段階がみられることがあげられる（東京都環 境局, 2011)。伊豆諸島は照葉樹林域であるが, 落葉広葉樹二次林や常緑広葉樹二次林が優勢であ る。例えば，伊豆大島の裸地では，八チジョウイ タドリ (Reynoutria japonica var. terminalis) や シマタヌキラン (Carex doenitzii subsp. okuboi) が代表する火山荒原となり，それはやがてオオバ ヤシャブシ (Alnus sieboldiana) などの低木林に 変わり，さらにオオバエゴノキ (Styrax japonica var. kotoensis), オオシマザクラ (Cerasus speci-

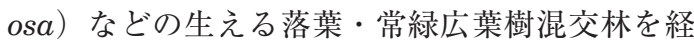
て林下にオオシマカンスゲ (Carex oshimensis) を伴うスダジイ林の常緑広葉樹林となる。
表 2 伊豆諸島のおもな島々 $\left(1 \mathrm{~km}^{2}\right.$ 以上）の面積と 維管束植物の分類群 (可知, 2011).

Table 2 Areas and numbers of vascular plants on 11 islands of Izu (data from Kachi, 2011).

\begin{tabular}{lrcl}
\hline & 面積 $\left(\mathrm{km}^{2}\right)$ & 維管束植物の分類群数* \\
\hline 大島 & 91.1 & $806,662,777$ \\
利島 & 4.1 & $609,282,552$ \\
新島 & 23.9 & $639,290,505$ \\
式根島 & 3.9 & $357,164,322$ \\
神津島 & 18.9 & $546,389,642,577$ \\
三宅島 & 55.4 & $551,600,647$ \\
御蔵島 & 20.6 & $527,528,516$ \\
八丈島 & 69.5 & $662,702,786$ \\
八丈小島 & 3.1 & & \\
青ヶ島 & 6.0 & $358,253,215$ \\
鳥島 & 4.8 & 95,91 \\
\hline
\end{tabular}

複数の資料に基づく.

\section{3-2）小笠原諸島}

小笠原諸島は東京本土部から南南東約 $1000 \mathrm{~km}$ の太平洋上に位置する島々で，聟島列島，父島列 島，母島列島，西之島，火山列島（硫黄列島）な どの各島からなる。気候は西熱帯性で比較的雨量 は少ない（例えば父島の場合は年 $1300 \mathrm{~mm}$ 程 度)。小笠原諸島は大陸と陸続きになったことが ない海洋島であり, 特異な島嶼景観が形成されて いる（宮脇, 1989; 畑・可知, 2011）。小笠原諸島 における人為影響の歴史は比較的短い。北硫黄島 (硫黄列島）には先史時代のものと思われる遺跡 があるものの, 江戸時代の 1675 年に新しく発見 された。19 世紀になると捕鯨船が寄航するよう になり，1830 年にナセニエル・セボレーらが父 島 (奥村) に入植し，はじめての移住民となった。 小笠原で人間活動が活発になったのはそれ以降で ある。

特徵的な植生の一つに乾燥に強い形態に進化し たシマイスノキ (Distylium lepidotum) やムニ ンヒメツバキ (Schima mertensiana) などが優 占する樹高 $5 \sim 8 \mathrm{~m}$ 程度の低木から構成される 乾燥低木林があげられる。また，母島の石門には シマホルトノキ (Elaeocarpus photiniaefolius) やウドノキ（Pisonia umbellifera）などから構成 
される湿性高木林が成立する。本土部や伊豆諸島 とは異なり，小笠原諸島の植生にはブナ科の樹木 が欠如していることも大きな特徴である（宮脇, 1989)。

小笠原の生物相の特徵としてまずあげられるの は，固有率の高さであろう。小笠原の主要 5 島 （聟島，弟島，兄島，父島，母島）において確認 された維管束植物種は計 688 種で，そのうち 150 種が固有種であった（環境省自然環境局, 2004）。 また，無脊椎動物相の固有種の割合も多く, $\mathrm{Hi}$ rasea 属や Mandarina 属のカタッムリなどで適 応放散の事例がみられる。小笠原の植物相は東 南アジアの亜熱帯起源のものが多いが，日本本土 起源, オセアニア起源の植物種もみられる（清水, 2010)。

一般に大陸から遠く離れた孤島では，草本植物 の木本化や体サイズの巨大化，散布能力の低下な ど，大陸とは異なる特徴が知られており，それら はアイランド・シンドロームなどと呼ばれている (Carlquist, 1978)。小笠原でみられる固有種に は雌雄性の分化や草本の木本化など進化の過程を 示すさまざまな種分化の形態がみられ，海洋島に 独特の進化様式を観察することができる。

\section{4）伊豆諸島と小笠原諸島における生物多様性} の現状

伊豆諸島および小笠原諸島で絶滅が危惧され る，もしくは絶滅した種として選定されたのは伊 豆諸島で 348 種，小笠原諸島で 169 種であった (図 5)。これらの数は 1998 年の評価の時から, 伊豆諸島で 42 種, 小笠原諸島で 48 種増加し, 開発などによる自然環境の攪乱，食害の影響など が原因と考えられている。伊豆諸島では 1 種（才 ナモミ(Xanthium strumarium)）が，小笠原諸 島では 3 種（ハナヤスリ科・イオウジマハナヤ スリ (Ophioglossum nudicaule)，キク科・トヨ シマアザミ(Cirsium toyoshimae)，ラン科・ム ニンヌキラン (Zeuxine boninensis)) が絶滅し たと判定された（東京都環境局, 2011）。

\section{4-1）伊豆諸島}

伊豆諸島には固有，準固有と考えられる種，亜 種，変種が 54 あるが，第四紀になってから形成さ



図 5 伊豆諸島と小笠原諸島の保護上重要な植物種 のカテゴリー. EX : 絶滅種, CR：絶滅危惧 IA 類, EN : 絶滅危惧 IB 類, VU：絶滅危惧種 II 類， NT：準絶滅危惧種，DD：データ不足。東 京都環境局（2011）に掲載されているデー夕を もとに作成.

Fig. 5 Comparisons of numbers of threatened plant species between Izu islands and Bonin islands. EX: extinct, CR: critically endangered, EN: endangered, VU: vulnerable: NT; near threatened, and DD: data deficient. Data source: Bureau of Environment, Tokyo Metropolitan Government (2011).

れた歴史が比較的新しい島であることを考えると きわめて固有・準固有種の数が多い（宮脇, 1986）。 うち，伊豆諸島に固有の維管束植物は 18 種，21 変 種， 1 品種， 2 雑種あり，また 2 種， 1 変種は伊豆 諸島と伊豆半島に固有で，1種が伊豆諸島と小笠 原諸島にのみ分布している (Ohba and Akiyama, 2002)。

伊豆諸島の陸棲哺乳類相は本州よりも貧弱であ る。伊豆諸島には 19 種の野生の哺乳類が生息する と考えられるが，うち一種は海生哺乳類のニホン アシカ (Zalophus japonicus) である。食虫類と ネズミ類では，ジネズミ（Crocidura dsinezumi）, アカネズミ(Apodemus speciosus), ハツカネズ ミ(Mus musculus), ドブネズミ(Rattus norvegicus)，クマネズミが分布しているのみである (高田ほか, 2004)。ただし，これらは人為的にも ち达まれたものと考えられている（高田ほか， 
1999)。ネズミ類以外でも大島へのタイワンリス (Callosciurus erythraeus thaiwanensis) とタイ ワンザル (Macaca cyclopis), 新島へのニホンジ カ(Cervus nippon)，三宅島へのイタチ (Mustela itatsi)，八丈小島へのノヤギなどさまざまな哺乳 類が島へもち込まれており，在来生物や生態系へ の影響が懸念されている（島嶼生態系研究会ほか, 1996)。絶滅の恐れがある野生の哺乳類として は，キクガシラコウモリ (Rhinolophus ferrumequinum)，コキクガシラコウモリ (Rhinolophus cornutus), ユビナガコウモリ (Miniopterus fuliginosus), ニホンアシカ, アカネズミの 5 種 が選定されている（東京都環境局, 2011）。とく に, 洞穴性のコウモリ類については生息拠点であ る洞穴 (防空壕) の改変があるため, 保護上の配 虑が必要と考えられる。

\section{4-2）小笠原諸島}

小笠原の植生や植物種数も基盤の相違, 地史的 な古さの違いや面積により島ごとに異なる（表 3)。小笠原諸島の乾性低木林には 69 種の固有種 が確認され，固有種率は $67 \%$ と高いものの，干 ばつや台風などの覺乱だけでなく，ノヤギによる 採食などの影響による脅威がある（日本政府， 2010)。また, 残存個体数が 100 個体未満の希少 植物として，ムニンツツジ (Rhododendron boninense), コバトベラ (Pittosporum parvifolium), シマホザキラン (Malaxis boninensis), セキモン ノキ(Claoxylon centinarium), ハザクラキブシ (Stachyurus macrocarpus var. purnifolius), ウ チダシクロキ (Symplocos kawakamii)， ムニン ヒサカキ (Eurya japonica var. boninensis), ナガ バキブシ (Stachyurus macrocarpus var. macrocarpus）などがある。とくに，ムニンツツジは野 生株としては父島に 1 個体のみが残存するだけ であり，種の保存法（絶滅のおそれのある野生動 植物の種の保存に関する法律) に基づき, 保護増 殖事業が行われている（環境省・農林水産省, 2005)。

小笠原の哺乳類ではオガサワラアブラコウモリ (Pipistrellus sturdeei) はすでに絶滅し，オガサ ワラオオコウモリ（Pteropus pselaphon）の 1 種
表 3 小笠原諸島のおもな島々 $\left(1 \mathrm{~km}^{2}\right.$ 以上) の面積 と維管束植物の分類群 (可知, 2011).

Table 3 Areas and numbers of vascular plants on 14 islands of Bonin (data from Kachi, 2011).

\begin{tabular}{lccc}
\hline & 面積 $\left(\mathrm{km}^{2}\right)$ & 維管束植物の分類群数* \\
\hline 聟島 & 2.6 & $127, \quad 141$ \\
媒島 & 1.6 & 98 & \\
弟島 & 5.2 & $104, \quad 186$ \\
兄島 & 7.9 & $129, \quad 185$ \\
父島 & 23.8 & $313, \quad 355$ \\
母島 & 20.2 & $254, \quad 279$ \\
向島 & 1.5 & $81, \quad 89$ \\
姉島 & 1.4 & $43, \quad 82$ \\
妹島 & 1.2 & $63, \quad 98$ \\
姪島 & 1.1 & $39, \quad 76$ \\
北硫黄島 & 5.6 & $113, \quad 129$ \\
硫黄島 & 23.2 & 100, & 92 \\
南硫黄島 & 3.5 & 103, & 129 \\
南鳥島 & 1.5 & 52 & \\
\hline
\end{tabular}

複数の資料に基づく.

のみが現存する。オガサワラオオコウモリは東京 都ランクで絶滅危惧 IB 類 (EN), 環境省ランク で絶滅危惧 IA 類 $(\mathrm{CR})$ に分類されている。森林 に生息し，夜行性であるが，比較的市街地に近 い森林をねぐらとして, 行動圈が人里と重なる ため, 農業被害が深刻で, 害獣とみなされるこ ともある(稲葉ほか, 2002)。哺乳類ではないが, 鳥類の固有覀種であるオガサワラカワラヒワ (Carduelis sinica kittlitzi)，アカガシラカラス バト (Columba janthina nitens) は生息数の減少, 生育環境の悪化が顕著であり, 絶滅が危惧されて いる。2012 年に, 1990 年代以降に生息が確認さ れておらず，絶滅の可能性が指摘されていた海鳥 ミズナギドリの一種ブライアンズ・シアウォータ (Puffinus bryani) が小笠原諸島で再発見された (森林総合研究所, 2012)。ブライアンズ・シア ウォーターの和名として，小笠原に生息する小型 のミズナギドリという意味でオガサワラヒメミズ ナギドリという名前が提案されている。このよう な発見は小笠原諸島の生態系は生物学的にきわめ て高い価值をもつことを改めて示すものである。 


\section{III. 生物多様性の保全に向けた取り組みと展望}

東京における生物多様性現状は他の地域と同様 に必ずしも楽観できるものではない。以降，国内 外の動向を踏まえながら，危機の種類（表 1）ご とに, 東京の生物多様性に関する課題と展望を述 ベる。

第一の危機，すなわち人間活動や開発による危 機については, 明治以降の都市化に伴い大きく増 大したものの，現在は改善に向かっているものと 考えられる。多くの野生生物が生息することがで きる自然環境の面積は戦後の市街地の拡大ととも に減少してきた。すでに絶滅したと考えられてい るカワウソは 20 世紀初頭には東京府東京市下谷 区（現在の台東区の西部）, 滝野川区（現在の北 区南部）など不忍池に流入する藍染川（谷田川） に多数生息していたことが報告されている（岸田， 1934)。イノシシ (Sus scrofa) でさえ，1850 年 くらいまでは本郷や小石川に生息していたようで ある。第二次世界大戦前までは都心においてもイ タチ，キツネ，タヌキなどの中型哺乳類が生存し ていた（沼田・小原, 1982）。東京都稲城市百村 周辺でッキノワグマが捕獲されたという記録も残 されている(パルテノン多摩, 2010)。しかし, 戦 後都市化が進むにつれて，動物の生息域が都心か ら西へと狭まっていく退行現象がみられた（千羽， 1973）。自然環境保全調査報告書（環境庁自然保 護局, 1976）によれば 1973 年には東京都の約 $40 \%$ が緑のほとんどない市街地等で占められ, 立川附近までほとんど緑のない地区となってい た。かつて武蔵野の雑木林として知られた近郊地 も，多摩ニュータウンをはじめとする大規模な宅 地造成のためにみるかげもなく，田畑や小規模な 樹林地がわずかに残されているだけであった。そ のため, 食肉性のキッネやイタチは営巣地の消 滅, 採餌地の減少によって生息地が急速に退行し た。

経済発展に伴う公害や自然環境の破壊への反省 から，昭和後期から平成にかけて自然への関心が 高まり，都市を含めた開発への取り組みが変化し， 自然環境が改善しつつある状況といえる（田畑，
2011）。東京でも，1972 年に「東京都における自 然の保護と回復に関する条例（昭和 47 年東京都 条例第 108 号)」が公布され，2007 年には「緑の 東京 10 年プロジェクト」を策定し, 緑の拠点を 街路樹で結ぶ「グリーンロード・ネットワーク」 の形成や「海の森」の整備など，とくに都市域に おける緑地環境の整備を進めている。

このような自然環境の保全に対する取り組みは 東京の生物多様性の保全へとつながると期待され るが，一方で新たなる問題が生じさせる可能性が ある。2009 年 7 月にイノシシが首都大学東京の 南大沢キャンパス（八王子市南大沢）に生育して いることが確認された。イノシシは八王子市北部 や西部においては農業被害も多く報告されている が，東部地区では生息は確認されていなかった (Arima et al., 2010)。この事例は, いくつかの 野生生物がその生息域を拡大しつつあることを示 すものである。これらの比較的豊かな自然が起点 となって，都市域や郊外における野生生物の突発 的な出現や農業被害などが増加しており，野生生 物と人間社会の軋轢の解消は東京のような自然環 境の保全を進める都市の課題の一つとなる可能性 がある。

第二の危機，里山など八間活動の縮小による生 じている危機については，とくに多摩地域のよう な二次的自然環境が残されている地域でとくに深 刻な問題といえる。このような二次的自然環境に おいては，雑木林のように人間が利用することで 形成されてきた環境に適応してきた多くの生物が 生息し，そのような生物の多くが絶滅の危惧に瀕 している。多摩地域に残された二次的自然には, タマノホシザクラ (Cerasus tamaclivorum) のよ うな多摩丘陵に固有で絶滅の恐れがあるといわれ る植物種も生息している（Oohara et al., 2004）。 多摩川河川敷のに生育するカワラノギク (Aster kantoensis）は，洪水によって形成される玉石河 原にのみ生育することができるが，水利施設の整 備に伴い洪水発生区域が限定されるようになって から，個体数の減少が著しく，絶滅が危惧されて いる（倉本ほか, 2000）。

里地里山に現在残されている二次的自然は社会 
経済の構造的な変化に伴い自然環境の利用が縮小 し, 水田等の農地や二次林・二次草原などによる モザイク性やそのネットワークが失われつつあ る。これらの問題を解決するためには，伝統的な 自然の管理，すなわち小規模な伐採や下草刈りな どを継続的に行う必要がある。

COP-10において採択された SATOYAMA イ ニシアティブは世界各地に存在する持続可能な自 然資源の利用形態や社会システムを収集・分析 し，地域の環境がもつポテンシャルに応じた自然 資源の持続可能な管理・利用のための共通理念を 構築し, 世界各地の自然共生社会の実現に活かし ていく取り組みである（環境省生物多様性地球戦 略企画室, 2010; Takeuchi, 2010)。このイニシア ティブでは, 多様な生態系のサービスと価值の確 保のための知恵の結集，革新を促進するための伝 統的知識と近代科学の融合, 伝統的な地域の土地 所有・管理形態を尊重した上での，新たな共同管 理のあり方が行動指針としてあげられ，SATOYAMA イニシアティブ国際パートナーシップが 中心となって, 理解と意識を高め, ランドスケー プを維持，再構築するための活動の支援が行われ ている。このような国際的な取り組みと連携しな がら，二次的自然の保全や管理を行うための方針 を再構築することが求められる。

しかし, 社会コストの増大に直面し, 慢性的に 財政難を抱える自治体に二次的自然の管理におけ るすべての責任を負わせていくことはあまり建設 的ではないだろう。二次的自然環境は余暇空間, リラックス，社交の場として都市住人の暮らしの ための大切な自然資源である。そこで, 環境 NPO など，都市住民が参加することができる自然環境 の保全活動が期待されている（田中ほか, 2003; 辰井・藤井, 2006; 中島ほか, 2007)。既存のレク リエーション利用に加え, 環境教育やエコッーリ ズム，バイオマスの利用などの，生物多様性の視 点に立った自然資源の利用促進を図るためには, それらの運営を支えるための組織的支援が必要で あろう。近年, 都市の生物多様性の保全に向け て，個人住宅の庭や社寺林など民有地に残された 森林などの重要性も強調されている (Goddard et $a l ., 2009$; Ishii et al., 2010)。多くの保全活動は公 有地で行われることが多いが (栗田・植竹, 1999), 民有地に残された二次的自然環境の保全に取り組 むためのメカニズムも今後重要になる。これま で，東京でも行政や NPO が主体となって，自然 環境の保全, 創出のための取り組みを推進し, 多 くの自然環境が新たに整備, 創出されてきた。今 後はさまざまな土地に偏在する自然環境の生態学 的ネットワークを踏まえ, 地域の自然環境を包括 的に維持，管理していくための仕組みが求められ る。

第三の危機，人間によりもち込まれた外来種 などによる生物多様性の危機は, 外来種に対し てとくに脆弱な生態系を有する小笠原諸島にお いて，きわめて深刻である（例えば, Kawakami and Okochi, 2010)。グリーンアノール (Anolis carolinensis)，ノヤギ，ノネコ，クマネズミな ど外来生物による固有の動植物の捕食に加えて, モクマオウ (Casuarina equisetifolia)，アカギ (Bischofia javanica) などの外来植物も在来植物 の生存を脅かしている。小笠原の固有植物は花粉 不足のため種子の結実量が少なくなっていること が報告されている。小笠原固有種の送粉を担う在 来ハナバチがグリーンアノール (Anolis carolinensis）によって捕食され，個体数が減少してい ることに加えて，花粉交配用に導入されたセイヨ ウミツバチ (Apis mellifera) による盗蜜（受粉 を行わず花蜜のみをもち去ること）も原因と考え られている(Abe et al., 2008; 安部, 2009)。

小笠原諸島は 2011 年 6 月に日本で 4 番目とな る世界自然遺産に登録された。2003年から世界 自然遺産の登録へ向けた取り組みがはじまり, 外 来種駆除事業，保護・管理制度の整備，モニタリ ング事業などが行われた。このような取り組みに よって外来種による脅威は深刻な状態から脱しつ つあると考えられる。ただし，現在，複数の機関 によって積極的に行われている外来種駆除事業 は，結局のところ多くの外来種の命を奪うことを 意味しており，人間の都合による駆除を正当化す ることに対する葛藤も住民のなかで表面化しつつ ある（鈴木, 2010）。そのため，小笠原諸島とし 
て外来種駆除事業をいつまで行うのか，そして現 在の外来種をどこまで受け入れるべきなのかを議 論し，決定する必要があるだろう。

本土部でも多くの侵略的外来種（特定外来生物, 要注意外来生物）の問題は無視できない。千葉県 などの関東近辺においては外来種の増加傾向にあ り，東京でも同様の傾向にあるものと推測される (北澤, 2010)。ペットなどとしてもち込まれたア ライグマ (Procyon lotor) は成獣になると凶暴化 し，捨てられることがあり，農業被害を引き起こ すだけでなく，狂犬病のような感染症の媒介者と なる恐れもある（環境省自然環境局生物多様性セ ンター, 2007)。この問題はペットの放棄など, 現代社会の生活様式や意識の変化と密接に関連し ており，東京のように人口が集中する大都市にお いてより深刻な問題になる可能性がある。

近年は都市政策において生物多様性に関する取 り組みも活発化している（大石, 2011）。2007 年 にブラジルのクリチバで開催された「都市と生物 多様性」に関する会議とその成果である「クリチ バ宣言」を受け，生物多様性保全における都市 の役割が重要視されるようになった。その後, 2008 年の COP-9 において科学者, 教育者, 計画 立案者等からなる国際ネットワークである「都市 と生物多様性は都市における生物多様性のデザイ

ン (URBIO: Urban Biodiversity and Design)」 が生物多様性条約の都市における実施に向けた科 学的実践アプローチを学術的に検討するために組 織化された（森本, 2011）。このURBIO が関連 する取り組みの一つに，1. 在来種の生物多様性, 2. 生態系サービス, 3. 生物多様性の統治と管理 の 3 種類の指標群からなる都市の生物多様性指 標 (CBI: City Biodiversity Index) の開発があげ られる。CBI は 2008 年 5 月にドイッで開催され たURBIOにおけるシンガポール政府の提案が契 機となって開発され，都市レベルの生物多様性を 評価する指標として位置づけられることが期待さ れている。ただし, 指標の対象や解釈については さまざまな議論がある（加藤, 2010）。さまざま な自然環境を有する東京の生物多様性を可視化 し，生物多様性におけるさまざまな取り組みにお
いて利用可能な CBI 指標の開発を目指すべきで ある。

東京は都市生態系だけでなく，里地里山に代表 される二次的な自然，そして伊豆諸島や小笠原諸 島のような世界的にも貴重な自然環境と生物多様 性をもつ地域である。東京に打ける多くの自然環 境は多かれ少なかれ，人間の関わりをもちながら 存在しており，利用と保全のバランスをとるため の適切な管理が求められる。しかし，アメニティ や調整機能など社会の生態系サービスに対する要 求と生物多様性の保全への取り組みは時に矛盾す る。自然との関わりにおけるあるべき姿について 議論を深めながら, 生物多様性の保全と都市の社 会・経済活動を両立させるための基本理念を，具 体的な都市計画のなかで位置づけていくことが求 められる。

\section{謝 辞}

本稿をまとめるにあたり, 可知直毅教授（首都大学 東京・理工学研究科）から有益な助言をいただいた。 ここに御礼申し上げます。

\section{文献}

安部哲人 (2009): 小笠原諸島における送粉系擋乱の現 状とその管理戦略. 地球環境, 14, 47-55. [Abe, T. (2009): Ecological disrupt on and the management strategy of endemic pollination on system in the Ogasawara Islands. Global Environment Research (Chikyu Kankyo), 14, 47-55. (in Japanese) ]

Abe, T., Makino, S. and Okochi, I. (2008): Why have endemic pollinators declined on the Ogasawara Islands?. Biodiversity and Conservation, 17, 14651473.

Arima, T., Noda, E., Iki, M., R., R.E.H., Shirayanagi, K., Naito, S., Yamasuge, K., Nakamura, R., Yabe, N. and Numata, S. (2010): Existence and migration routes of large mammals in urban landscape: Discovery of a wild boar in the campus greenbelt. URBIO2010, Proceedings of the 2nd International Conference of Urban Biodiversity and Design, Nagoya, Japan, 234.

Carlquist, S. (1978): Island Biology. Columbia University Press.

千羽晋示 (1973): 動物の生息環境の変化と退行現象. 自然科学と博物館, 40, 69-73. [Chiba, S. (1973): Changes in animal habitats: Declination of animal inhabitation in urban area. Shizen Kagaku To Hakubutsukan, 40, 69-73. (in Japanese) * ]

遠藤秀紀・倉持利明・川嶋 舟・吉行瑞子 (2000): 皇 居内に移入されたハクビシンとタヌキについて．国 
立科学博物館専報, 35, 29-33. [Endo, H., Kuramochi, T., Kawashima, S. and Yoshiyuki, M. (2000): On the masked palm civet and the raccoon dog introduced to the Imperial Palace, Tokyo, Japan. Memoirs of the National Science Museum, 35, 2933. (in Japanese) ]

藤森隆郎・由井正敏・石井信夫 (1999): 森林における 野生生物の保護管理一生物多様性の保全に向けて。 日本林業調査会. [Fujimor, T., Yui, M. and Ishii, N. (1999): Protection and Management of Forest Wildlife: Towards a Conservation of Biodiverstiy (Shinrin Ni Okeru Yasei Seibutsu No Hogo Kanri). Japan Forestry Investigation Committee. (in Japanese) *]

Goddard, M.A., Dougill, A.J. and Benton, T.G. (2009): Scaling up from gardens: Biodiversity conservation in urban environments. Trends in Ecology \& Evolution, 25, 90-98.

畑 憲治・可知直毅 (2011) : 野外研究サイトから (18) 小笠原諸島. 日本生態学会誌, 61, 227-232. [Hata, K. and Kachi, N. (2011): The Ogasawara (Bonin) Islands (From field research sites (18)). Japanese Journal of Ecology, 61, 227-232. (in Japanese) ]

Ichikawa, K., Okubo, N., Okubo, S. and Takeuchi, K. (2006): Transition of the Satoyama landscape in the urban fringe of the Tokyo metropolitan area from 1880 to 2001. Landscape and Urban Planning, 78, 398-410.

稲葉 慎 - 高槻成紀 - 上田恵介 - 伊澤雅子 - 鈴木 創 · 堀越和夫 (2002): 個体数が減少したオガサワラオオ コウモリ保全のための緊急提言. 保全生態学研究, 7, 51-61. [Inaba, M., Takatsuki, S., Ueda, K., Izawa, M., Suzuki, H. and Horikosi, K. (2002): An urgent appeal for conservation of the Bonin flying fox, Pteropus pselaphon Layard, an endangered species. Japanese Journal of Conservation Ecology, 7, 5161. (in Japanese) *]

Ishii, H., Manabe, T., Ito, K., Fujita, N., Imanishi, A., Hashimoto, D. and Iwasaki, A. (2010): Integrating ecological and cultural values toward conservation and utilization of shrine/temple forests as urban green space in Japanese cities. Landscape and Ecological Engineering, 6, 307-315.

可知直毅 (2011): 伊豆諸島と小笠原諸島の特徵一島の 成立過程と自然環境，生物相の概観. 可知直毅・村 上哲明編：東京都の島の植物と生物多様性一伊豆諸 島から小笠原まで. 日本植物学会, 6-13. [Kachi, N. (2011): Characteristics of Izu and Bonin islands; Process of the formations, environment, and biota of Izu and Bonin islands. in Plants and Biodiversity of Islands in Tokyo: From Izu Islands to Bonin Islands (Tokyoto No Shima No Shokubutsu To Seibutsu Tayosei) edited by Kachi, N. and Murakami, T., 6-13. (in Japanese) *]

上條隆志・奥富 清 (1993): 八丈島におけるスダジイ 林とタブノキ林の分布とその成因. 日本生態学会誌, 43, 169-179. [Kamijo, T. and Okutomi, K. (2011):
The distribution of Castanopsis and Persea forests and its causal factors were studied on Hachijo-jima in the Izu Islands. Japanese Journal of Ecology, 43, 169-179. (in Japanese) ]

環境庁自然保護局 (1976): 自然環境保全調査報告書 (第 1 回緑の国勢調査). [Nature Conservation Bureau, Ministry of Environment of Japan (1976): Report of the National Survey on the Natural Environment (1st Census) (Shizen Kankyo Hozen Chosa Hokokusho Dai 1 Kai Midori No Kokusei Chosa). (in Japanese)*]

環境省 (2010): 生物多様性国家戦略 2010. [Ministry of Environment of Japan (2010) : National Strategy for the Conservation and Sustainable Use of Biological Diversity 2010. (in Japanese) ]

http://www.env.go.jp/nature/biodic/nbsap2010/ attach/01_mainbody.pdf [Cited 2012/2/15].

環境省自然環境局 (2004): 平成 15 年度小笠原地域自 然再生推進計画調査 (その 2). [Nature Conservation Bureau, Ministry of Environment of Japan (2004): Survey of Bonin Island Area for Promotion of Nature Restoration. No.2 (Heisei 15 Nendo Ogasawara Chiiki Shizen Saisei Suishin Keikaku Chosa Sono 2). (in Japanese)*]

環境省自然環境局生物多様性センター (2007): 平成 18 年度自然環境保全基礎調査 種の多様性調査（アラ イグマ生息情報収集）業務報告書. [Biodiversity Center of Japan, Nature Conservation Bureau, Ministry of Environment of Japan (2007): Project report of the National Survey on the Natural Environment: Habitat Information of Common Raccoon (FY2006) (Heise 18 Nendo Shizen Kankyo Hozen Kiso Chosa Shu No Tayosei Chosa (Araiguma Seisoku Joho Shushu) Gyomu Hokokusho). (in Japanese) *]

環境省生物多様性総合評価検討委員会 (2010)：生物多 様性総合評価報告書. [Japan Biodiversity Outlook Science Committee, Ministry of Environment of Japan (2010): Japan Biodiversity Outlook: Report of Comprehensive Assessment of Biodiversity in Japan (Seibutsu Tayosei Sogo Hyoka Hokokusho). (in Japanese) * ]

環境省生物多様性地球戦略企画室 (2010): SATOYAMA イニシアティブとは. [Global Biodiversity Strategy Office, Ministry of Environment of Japan (2010): What is Satoyama Initiative?. (in Japanese)*] http://satoyama-initiative.org/wp-content/uploads/ 2011/09/satoyama_leaflet_web_jp_final.pdf [Cited 2012/2/15].

環境省・農林水産省 (2005): ムニンツツジ保護増殖事業 計画. [Ministry of Environment of Japan and Ministry of Agriculture, Forestry and Fisheries of Japan (2005): Project of Protection and Multiplication of Rhododendron Boninense (Munin Tsutsuji Hogo Zoshoku Jigyo Keikaku). (in Japanese)*]

加藤正嗣 (2010): 役に立つ「都市の生物多様性指標 (CBI)」をめざして（特集 都市の生物多様性指標の 
開発に向けて). 日本緑化工学会誌，36，369-372. [Kato, M. (2011): How to use and improve the City Biodiversity Index. Journal of the Japanese Society of Revegetation Technology, 36, 369-372. (in Japanese) * ]

Kawakami, K. and Okochi, I. eds. (2010): Restoring the Oceanic Island Ecosystem-Impact and Management of Invasive Alien. Springer.

岸田久吉 (1934): 大東京の哺乳動物に就て. Lansania, 6, 17-30. [Kishida, K. (1934): The mammal fauna of the great city of Tokyo, Japan. Lansania, 6, 1730. (in Japanese) ]

北澤哲弥 (2010): 千葉県における野生生物の現状. 千 葉県生物多様性センター研究報告, 2, 65-69. [Kitazawa, T. (2010): Report of the Chiba Biodiversity Center, 2, 65-69. (in Japanese) ]

近田文弘・西川 肇・藤井寿生 - 工藤勝輝 - 村井 宏 伊藤忠夫 $(2000)$ : 皇居吹上御苑の森林植生. 国立科 学博物館専報, 34, 51-71. [Konta, F., Nishikawa, H., Fujii, H., Kudo, K., Murai, H. and Ito, T. (2000): Forest vegetation in the Fukiage Gardens of the Imperial Palace, Tokyo, Japan. Memoirs of the National Science Museum, 34, 51-71. (in Japanese) ] 小山博滋 - 近田文弘 - 土居祥㑆 - 渡辺眞之 ・柏谷博之 (2000): 皇居の生物相：I. 植物相. 国立科学博物館専 報, 34, 1-5. [Koyama, H., Konta, F., Doi, Y., Watanabe, M. and Kashiwadani, H. (2000): Flora and fauna of the Imperial Palace, Tokyo: I. Flora. Memoirs of the National Science Museum, 34, 1-5. (in Japanese) ]

倉本 宣·石濱史子・熟谷いづみ・嶋田正和・可知直毅・ 井上 健 - 加賀屋美津子 - 牧 雅之 ·竹中明夫 ·増田 理子 (2000): 多摩川のカワラノギク保全のための緊 急アピール (緊急アピール). 保全生態学研究, 5 , 199-196. [Kuramoto, N., Ishihama, H., Washitani, I., Shimada, M., Kachi, N., Inoue, K., Kagaya, M., Maki, M., Takenaka, A. and Masuda, M. (2000): Criteria for conservation of Aster kantoensis, a critically threatened plant on floodplain of the Tama river. Japanese Journal of Conservation Ecology, $\mathbf{5}$, 199-196. (in Japanese) ]

栗田和弥・植竹 薰 (1999): 関東地方における市民に よる環境 NPO の自然環境保全活動に関する研究. ラ ンドスケープ研究，62，400-404. [Kurita, K. and Uetake, K. (1999): Nature conservation volunteer activities of NPO in Kanto region, Japan. Journal of the Japanese Institute of Landscape Architecture, 62, 400-404. (in Japanese) ]

Millennium Ecosystem Assessment (2005): Ecosys tems and Human Well-being: Synthesis. Island Press.

宮本拓海 (2012): 東京都 23 区内の夕ヌキ，ハクビシン, アライグマの目撃情報の集計と分析 (2012 年 1 月版). [Miyamoto T. (2012): Analyses of Sighting Information on Japanese Raccoon Dog, Masked Palm Civet, and Common Raccoon (January 2012) (Tokyoto 23 Kunai No Tanuki, Hakubishin, Araiguma No
Mokugeki Joho No Shukei To Bunseki 2012 Nen 1 Gatu Ban). (in Japanese)*]

宮脇 昭編 (1986): 日本植生誌 関東. 至文堂. [Miyawaki A. ed. (1986): Vegetation of Japan vol.7 Kanto. Shibundo. (in Japanese)]

宮脇 昭編 (1989): 日本植生誌 沖縄 - 小笠原. 至文 堂. [Miyawaki A. ed. (1989): Vegetation of Japan vol.10 Okinawa and Ogasawara. Shibundo. (in Japanese) ]

森本幸裕 (2011): ランドスケープ分野からみた URBIO

日本開催と都市の生物多様性保全の展開（特集 生 物多様性とランドスケープーCOP10 に沸いた 2010 年 を未来につなぐ). ランドスケープ研究， 75，92-94.

[Morimoto, Y. (2011): Significance of URBIO 2010 from the view point of landscape architecture and its consequence. Journal of the Japanese Institute of Landscape Architecture, 75, 92-94. (in Japanese) ]

村中孝司・石濱史子編 (2010): 外来生物の生態学一進 化する脅威とその対策. 文一総合出版. [Muranaka, K. and Ishihama, F. (2010): Ecology of Introduced Organisms: Adaptive Evolution into New Environments and Possible Counter Measures. Bun-ichi. (in Japanese) ]

中島敏博 - 田代順孝・古谷勝則 (2007): 都市近郊住民 の利用および保全参加しやすい緑地と生活圈の距離. ランドスケープ研究，70，579-584. [Nakajima, T., Tashiro, Y. and Furuya, K. (2007): A Study on the distance inviting to use and participate the conservation activities between open-space and neighborhood extending by urban inhabitants. Journal of the Japanese Institute of Landscape Architecture, 70, 579-584. (in Japanese) ]

中静 透 (2011): 生物多様性の意味および COP10の 意義と課題. 環境技術，40，66-71. [Nakashizuka， T. (2011): Discussions on ecosystem services in CBD COP-10. Environmental Conservation Engineering, 40, 66-71. (in Japanese) ]

日本政府 (2010): 世界遺産一覧表記載推薦書 小笠原. [Government of Japan (2005): Nomination of the Ogasawara Islands for Inscription on the World Heritage List. (in Japanese) ]

沼田 眞 (1987): 都市の生態学. 岩波書店. [Numata, M. (1987): Urban Ecology (Toshi No Seitaigaku). Iwanami Shoten. (in Japanese)*]

沼田 眞 - 小原秀雄 (1982): 東京の生物史. 紀伊国屋 書店. [Numata, M. and Obara, H. (1982): Biology of Tokyo (Tokyo No Seibutsushi). Kinokuniya Shoten. (in Japanese) *]

Ohba, H. and Akiyama, S. (2002): A synopsis of the endemic species and intraspecific taxa of vascular plants of the Izu islands. Memories of National Science Museum, 38, 119-160.

Oohara, T., Serizawa, S. and Wakabayashi, M. (2004): A new species of Prunus (Rosaceae) from the Tama Hills, West Tokyo, Japan. Journal of Japanese Botany, 79, 343-349.

大石智弘 (2011): 生物多様性と都市政策 (特集 生物多 
様性とランドスケープ-COP10 に沸いた 2010 年を未 来につなぐ). ランドスケープ研究， 75， 97-99. [Ooishi, T. (2011): Biodiversity and urban policy. Journal of the Japanese Institute of Landscape Architecture, 75, 97-99. (in Japanese) ]

大山昌子（1999): 平成 11 年度伊豆諸島新島・式根島に おけるフロラ多様性と植物群落の多様性の研究. 新島 村博物館年報, 72-97. [Ooyama, M. (1999): A study on diversities of flora and plant communities on Niijima and Shikinejima islands (FY1999). Niijimamura Museum, 72-97. (in Japanese)*]

尾崎研一・堀江玲子・山浦悠一・遠藤孝一・野中 純・ 中鴆友彦 (2008): 生息環境モデルによるオオタカの 営巣数の広域的予測 : 関東地方とその周辺. 保全生 態学研究, 13, 37-45. [Ozaki, K., Horie, R., Yamaura, Y., Endo, K., Nonaka, J. and Nakashima, T. (2008): A habitat model for predicting the spatial distribution of Northern Goshawk nests in and around Kanto district, central Japan. Japanese Journal of Conservation Ecology, 13, 37-45. (in Japanese) ]

パルテノン多摩 (2010): 多摩のどうぶつ物語—ほ乳類 が見た地域の歴史一. パルテノン多摩. [ParthenonTama (2010): Wildlife in Tama Area: Local History from the View Point of Mammals (Tama No Dobutsu Monogatari). Parthenon Tama. (in Japanese)*]

プリマック，R.B.・小堀洋美 (2008): 保全生物学のす す女 改訂版. 文一総合出版. [Primack, R.B. and Kobori, H. (2008): A Primer of Conservation Biology. Bun-ichi. (in Japanese)]

Puppim de Oliveira, J.A., Balaban, O., Doll, C.N.H., Moreno-Peñaranda, R., Gasparatos, A., Iossifova, D. and Suwa, A. (2011): Cities and biodiversity: Perspectives and governance challenges for implementing the convention on biological diversity (CBD) at the city level. Biological Conservation, 144, 1302-1313.

Secretariat of the Convention on Biological Diversity (2010): Global Biodiversity Outlook 3, Montréal.

清水善和 $(2010)$ : 小笠原諸島に学ぶ進化論一閉ざされた 世界の特異な生き物たち一。技術評論社. [Shimizu, Y. (2010): Lessons from Bonin Islands: Unique Plants and Animals in a Closed World (Ogasawara Shoto Ni Manabu Shinkaron). Gijutsu-Hyohron. (in Japanese)*]

森林総合研究所 (2012): 絶滅したと思われていたミズ ナギドリの希少種を小笠原諸島で再発見一世界自然 遺産に生き残っていた希少鳥類一（プレスリリース）.

[Forestry and Forest Product Research Institute (2012): Rediscovery of a extinct bird species, Bryan's shearwater (Puffinus bryani) in Bonin islands. (in Japanese) *]

http://www.ffpri.affrc.go.jp/press/2012/20120207/ documents/20120207.pdf [Cited 2012/2/15].

首都大学東京牧野標本館 $(2010)$ : 海洋島植物標本デー タベース. [Makino Herbarium, Tokyo Metropolitan University (2010): Database of plant speci- mens in oceanic islands. (in Japanese)*]

http://wwwmakdb.shizen.se.tmu.ac.jp/makino/ home.php [Cited 2012/2/15].

鈴木 創 $(2010)$ :きれいごとでは済まない人と自然の共 生. 島嶼共生系学際研究環 平成 21 年度 実績報告

書. [Suzuki, H. (2010): Difficulty of symbiosis with nature. Annual Report of Consortium for the Interdisciplinary Study of Human and Nature Symbiosis in Island Systems (FY2009). (in Japanese)*]

田畑貞寿 (2011): 緑と地域計画 II 緑被地と空間機能. 古今書院. [Tabata, S. (2011): Green and Regional Planning II: Green Coverage and Spatial Function (Midori To Chiiki Keikaku 2). Kokon Shoin. (in Japanese) *]

高田靖司・酒井英一・植松 康 - 立石 隆 (1999): 伊 豆諸島における小哺乳類の分布. 日本生物地理学会 会報，54，9-19. [Takada, Y., Sakai, E., Uematsu, Y. and Tateishi, T. (1999): Distribution of small mammals on the Izu islands. Bulletin of the Biogeographical Society of Japan, 54, 9-19. (in Japanese)]

高田靖司・植松 康・酒井英一 - 立石 隆 (2004): 島 におけるジネズミの形態分化. 哺乳類科学，44，1724. [Takada, Y., Uematsu, Y., Sakai, E. and Tateishi, T. (2004): Morphological differentiation of island populations of Japanese white-toothed shrews, Crocidura dsinezumi. Mammalian Science, 44, 17-24. (in Japanese) ]

武田正倫・松浦啓一・野村周平 - 大和田 守 - 友国雅章 篠原明彦 (2000): 皇居の生物相 : II. 動物相（昆虫類 を除く)。国立科学博物館専報, 35，1-5. [Takeda, M., Matsuura, K., Nomura, S., Owada, M., Tomokuni, M. and Shinohara, A. (2000): Flora and Fauna of the Imperial Palace, Tokyo: II. Fauna, excluding insects. Memoirs of the National Science Museum, 35, 1-5. (in Japanese) ]

Takeuchi, K. (2010): Rebuilding the relationship between people and nature: The Satoyama Initiative. Ecological Research, 25, 891-897.

武内和彦・熟谷いづみ・恒川篤史編 $(2001)$ : 里山の環 境学. 東京大学出版会, 257p. [Takeuchi, K., Washitani, I. and Tsunekawa, A. (2001): SATOYAMA: The Traditional Rural Landscape of Japan (Satoyama No Kankyogaku). Tokyo University Press, 257p. (in Japanese)*]

田中聖美・柳井重人・丸田頼一（2003）：都市における 行政と市民団体との連携による樹林地保全に関わる 行政担当者の現状認識. ランドスケープ研究，65, 809-814. [Tanaka, K., Yanai, S. and Maruta, Y. (2003): A study on the consciousness of officers on forest conservation and on the partnership between the local governments and civic groups in cities. Journal of the Japanese Institute of Landscape Architecture, 65, 809-814. (in Japanese) ]

辰井美保・藤井英二郎 (2006): 市民による里山管理活 動が植生と参加者の意識に与える影響. ランドス ケープ研究, 69, 777-780. [Tatsui, M. and Fujii, E. 
(2006) : Effect of Satoyama preservation activity by civic group on vegetation and participants' awareness. Journal of the Japanese Institute of Landscape Architecture, 69, 777-780. (in Japanese)]

東京都環境保全局 (1998): 東京都の野生生物種目録.

[Bureau of Environment, Tokyo Metropolitan Government (1998): List of Wildlife Species of Tokyo Prefecture (Tokyoto No Yasei Seibutsushu Mokuroku). (in Japanese)* ]

東京都環境局 (2010): 東京都の保護上重要な野生生物 種 (本土部) 一東京都レッドリスト—2010 年版.

[Bureau of Environment, Tokyo Metropolitan Government (2010): Threatened Species of Tokyo Prefecture (Mainland Portion: Tokyo Red List 2010 (Tokyoto No Hogojo Juyo Na Yasei Seibutsushu (Hondobu) Tokyoto Reddo Risuto 2010 Nen Ban). (in Japanese) * ]

東京都環境局 (2011): 東京都の保護上重要な野生生物 種（島しょ部）一東京都レッドリストー2011 年版.

[Bureau of Environment, Tokyo Metropolitan Government (2011): Threatened Species of Tokyo Prefecture (Izu and Bonin Islands): Tokyo red list 2011 (Tokyoto No Hogojo Juyo Na Yasei Seibutsushu (Toshobu) Tokyoto Reddo Risuto 2011 Nen Ban). (in Japanese)* ]

東京都環境局 (2012): 保全地域の指定状況. [Bureau of Environment, Tokyo Metropolitan Government (2012): Status of protected areas. (in Japanese)*] http://www.kankyo.metro.tokyo.jp/nature/natural environment/tokyo/area/index.html [Cited 2012/ $2 / 22$.

東京都都市整備局 (2008): 東京の土地利用 平成 18 年 東京都区部. [Bureau of Urban Development, Tokyo Metropolitan Government (2008): Land Use in Tokyo Prefecture (the 23 wards) (Tokyo No Tochi Riyo Hesei 18 Nen Tokyoto Kubu). (in Japanese)*] 東京都都市整備局 (2009): 東京の土地利用 平成 19 年 多摩・島しょ地域. [Bureau of Urban Development,
Tokyo Metropolitan Government (2009): Land Use in Tokyo prefecture (Tama Area) (Tokyo No Tochi Riyo Heisei 19 Nen Tama, Tosho Chiiki). (in Japanese) *]

島嶼生態系研究会・長谷川雅美・浅田正彦・黒住耐二・ 関 啓一・黑野博之・矢野聡美・谷口薰美 (1996): 伊豆諸島，新島および神津島における食物連鎖構造 の解明と移入動物の影響. 第 5 回プロ・ナトゥーラ・ ファンド助成成果報告書. [Island Ecology Study Group: Hasegawa, M., Asada, M., Kurozumi, T., Seki, K., Kurono, H., Yano, S. and Taniguchi, K. (1996): Influences of introduced animals on food web structures of Nii-jima and Kozu-shima, the Izu Islands. Working Papers of the 5th PRO NATURA FUND. (in Japanese)]

熟谷いづみ・矢原徹一 (1996): 保全生態学入門一遺伝 子から景観まで．文一総合出版． [Washitani, I. and Yahara, T. (1996): An Introduction to Conservation Biology: From Gene to Landscape. Bun-ichi. (in Japanese) ]

渡邊綱男 ·鳥居敏男 - 守分紀子 (2011): 生物多様性と 環境行政一COP10 の成果と愛知目標の達成に向けた 今後の展開（特集生物多様性とランドスケープCOP10 に沸いた 2010 年を未来につなぐ). ランドス ケープ研究, 75, 85-88. [Watanabe, T., Torii, T. and Moriwake, N. (2011): Environmental policy and biodiversity: Outcome of COP10 and future perspective for achieving Aichi targets. Journal of the Japanese Institute of Landscape Architecture, 75, 85-88. (in Japanese) ]

Wilson, E.O. and Peter, F.M. eds. (1988): Biodiversity. National Academy Press, 521p.

矢原徹一 一川窪伸光編 (2002): 保全と復元の生物学一野 生生物を救う科学的思考. 文一総合出版. [Yahara, T. and Kawakubo, N. (2002): Biology of Conservation and Restoration. Bun-ichi. (in Japanese) ]

* Title etc. translated by S.N. 